\title{
Cane Stabilization Improves Yield of Red Raspberry (Rubus idaeus L.)
}

\author{
Justine E. Vanden Heuvel ${ }^{1}$, J. Alan Sullivan ${ }^{2}$, and John T.A. Proctor \\ Department of Plant Agriculture, Horticultural Science Division, University \\ of Guelph, Guelph, ON Canada N1G 2W1
}

Additional index words. yield potential, trellising, leaf area, floricanes

\begin{abstract}
Treatments of either staked (stabilized) or not staked (control, freestanding) canes were applied to Rubus idaeus L. 'Boyne' and 'Regency' during the 1997 and 1998 seasons to determine the effect of stabilizing fruiting canes in a windy environment. Treatments were applied in late April of each year, and canes were removed following harvest for growth analysis. Stabilizing (staking) floricanes increased yield per cane in 'Boyne' by $68 \%$ and in 'Regency' by $189 \%$, primarily through increases in fruit number per cane. Leaf area of the staked canes was $41 \%$ larger for 'Boyne' and $159 \%$ for 'Regency' than that of the control canes, suggesting that more leaf area was retained for photosynthesis, resulting in greater yield. Primocane diameter in 'Boyne' and primocane height in 'Regency' were also increased by staking, but floricane structure was unaffected.
\end{abstract}

Trellising changes a raspberry canopy in at least two ways: physical stress on the fruiting cane is reduced by preventing cane movement, and cane positions are manipulated to increase light penetration into the canopy, thereby increasing total plant photosynthetic capacity. However, the relative contribution of these two benefits has not been measured in raspberry.

The physiology of trunk stabilization has been studied in other perennial fruit crops. The two major consumers of carbohydrates in an apple (Malus $\times$ domestica Borkh.) tree are developing fruit and structural wood (Forshey and McKee, 1970; Forshey and Weires, 1983). When a physical stress such as wind sway is applied to fruit trees, the balance of carbohydrate utilization is changed and structural growth is promoted at the expense of fruit growth (Elfving and McKibbon, 1992; Perry, 1989). Supporting a fruit tree increases shoot growth, but decreases trunk diameter (Perry, 1989).

When plants are not supported, strong winds can reduce leaf area, plant height, and dry weight; increase leaf and fruit abrasion; and reduce yield (Grace, 1977; Proctor, 1982). Abrasion can severely damage leaves, resulting in a decrease in photosynthetically active leaf area (Grace, 1977). Restricting the movement of raspberry floricanes has been proposed as a possible means of increasing yield (Prive and Allain, 1998; Waister, 1970). Yield increases of almost $40 \%$ have been obtained by placing shelter screens of $63 \%$ permeability in front of the planting and perpendicular to

Received for publication 26 Apr. 1999. Accepted for publication 21 July 1999. This paper is a portion of a thesis submitted by Justine E. Vanden Heuvel. The cost of publishing this paper was defrayed in part by the payment of page charges. Under postal regulations, this paper therefore must be hereby marked advertisement solely to indicate this fact. ${ }^{1}$ e-mail address: jvandenh@uoguelph.ca

${ }^{2}$ To whom reprint requests should be addressed. the prevailing wind (Waister, 1970). The yield responses reflected differences in size of the fruiting framework resulting from differences in vegetative growth. These results were verified by Prive and Allain (1998) with four primocane fruiting raspberry cultivars by using artificial windbreaks to reduce wind velocity by $35 \%$. Raspberry plants in exposed sites had reduced leaf area; internode length; and leaf, cane, and total above-ground dry weight. The taller, sheltered raspberry plants had a more extensive fruiting framework, which resulted in a 2-fold yield increase.

The objective of these experiments was to measure the effect of cane stabilization on yield components and vegetative growth of two summer-bearing red raspberry cultivars.

\section{Materials and Methods}

Plant material. Prior to budbreak in 1997 , 32 red raspberry plants ('Boyne') were potted individually in 5 -gal $(\approx 19-\mathrm{L})$ nursery pots with Pro-Mix ${ }^{\circledR}$ (Premier Horticulture, Red Hill, Pa.). Densities were adjusted by pruning to three floricanes per pot. In 1998, 12 red raspberry plants ('Regency') were used. Procedures were similar to those used in 1997; however, density was adjusted to two floricanes per pot.

Treatments. Treatments consisted of a control (no support) and support. In 1997, four replications of eight pots each (four staked, four control) were placed in a north-south orientation outdoors in an unsheltered location. In 1998, three replications of four pots (two staked, two control) were used. A support system using wire and T-posts was constructed, and canes in the supported treatment were tied onto wires with nylon cord (Fig. 1). Canes in the control treatment were not supported and were free to move in the wind. Emerging primocanes remained unsupported in both treatments. Cane height and diameter were measured prior to treatment application. Plants were watered daily and fertilized twice weekly with $20 \mathrm{~N}-20 \mathrm{P}-20 \mathrm{~K}$ at $2 \mathrm{~g} \cdot \mathrm{L}^{-1}$.
Harvest. Each pot was treated as a separate experimental unit, and harvested individually every 2 or $3 \mathrm{~d}$ during fruiting season. All fruit were counted and weighed, and average fruit size was calculated as total yield divided by total fruit number on each harvest day. Harvest occurred between 6 July-2 Aug. 1997 for 'Boyne' and 3-14 July 1998 for 'Regency'. Yield was calculated and reported on a per cane basis for each plant. All fruit were considered marketable.

Leaf area. Immediately following harvest, all leaves were removed from the floricanes and total leaf area for each plant was measured using a LI-COR Li-3100 area meter (LI-COR, Lincoln, Nebr.). Average leaf area $\left(\mathrm{cm}^{2}\right)$ per floricane was calculated for each pot.

Growth analysis of floricanes. In late $\mathrm{Au}-$ gust, floricanes were cut at soil level, lateral number, node number, and percent budbreak were recorded and lateral length was measured for each cane. Canes were divided into thirds to determine the most productive portion of the cane. Percent budbreak per section was calculated as $100 \times$ number of laterals/ total bud number. Cane height above soil level and cane diameter (Max-Cal Electronic Digital Calipers; Cole-Parmer Instrument Co., Vernon Hills, Ill.) at $15 \mathrm{~cm}$ above soil level were also measured during growth analysis.

Growth analysis of primocanes. Primocane height, diameter, node number, and dry weight were measured on a per pot basis in midAugust. Primocane height was measured from soil level. Cane diameter $(\mathrm{mm})$ was measured at $15 \mathrm{~cm}$ above soil level. Primocanes from each pot were oven-dried for $5 \mathrm{~d}$ at $50{ }^{\circ} \mathrm{C}$ before measurement of dry weights.

Analysis of data. Data for the two cultivars grown in separate years were analyzed separately. Covariate measurements of cane height and diameter were nonsignificant. Analysis of variance was completed using the General Linear Model technique in SAS (SAS Institute, Cary, N.C.).

\section{Results}

Yield per cane of 'Boyne' and 'Regency' in the stabilized treatment was $\approx 68 \%$ and $189 \%$ greater, respectively, than those in the freestanding (control) treatment (Table 1), due to an increase in fruit number. The staked canes of 'Regency' produced significantly more fruit per cane $(126 \%)$ (Table 1$)$ than did control canes. While the staked canes of 'Boyne' had $\approx 40 \%$ more fruit than did control canes, this difference was nonsignificant. For both 'Boyne' and 'Regency', staked canes tended to produce slightly larger fruit than did control canes (Table 1).

The higher-yielding canes in the staked treatment also had greater leaf area $(41 \%$ and $159 \%$ in 'Boyne' and 'Regency', respectively) than did control canes (Table 1), and their leaves appeared less abraded although no measurements were taken.

Stabilization of canes did not result in significant differences in any measure of growth of the floricane for 'Boyne' or 'Regency' when either portions of the cane (data 


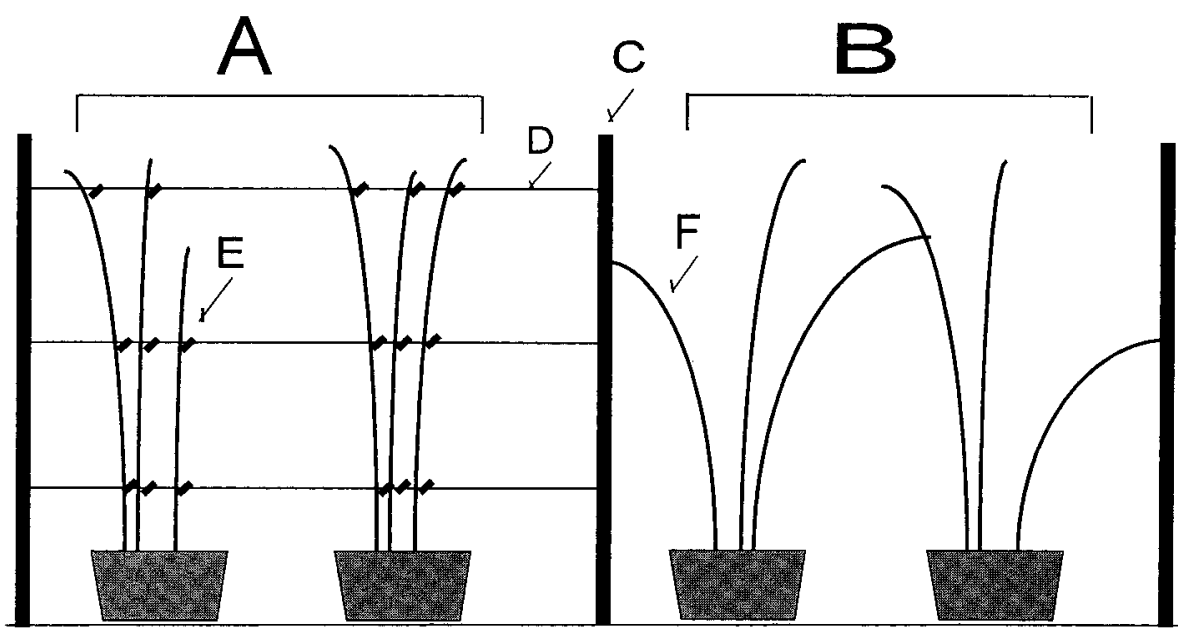

Fig. 1. Diagrammatic representation of one replication of experiment on 'Regency'. (A) stabilized treatment; (B) freestanding treatment; (C) T-post; (D) stabilization wire; (E) stabilized floricane; (F) freestanding floricane.

Table 1. Effect of staking on characteristics of floricanes of two red raspberry cultivars, 'Boyne' and 'Regency'.

\begin{tabular}{|c|c|c|c|c|c|}
\hline \multirow[b]{2}{*}{ Observation } & \multirow{2}{*}{$\begin{array}{l}\text { Cultivar: } \\
\text { Treatment: }\end{array}$} & \multicolumn{2}{|c|}{ Boyne } & \multicolumn{2}{|c|}{ Regency } \\
\hline & & Not Staked & Staked & Not Staked & Staked \\
\hline Yield/cane (g) & & 63.3 & $106.4^{*}$ & 35.1 & $101.4^{* * *}$ \\
\hline Average fruit weight $(\mathrm{g})$ & & 1.3 & $1.5^{\mathrm{Ns}}$ & 1.4 & $1.6^{\mathrm{NS}}$ \\
\hline Fruit no./cane & & 50.4 & $70.6^{\mathrm{Ns}}$ & 34.3 & $77.8^{*}$ \\
\hline Leaf area/cane $\left(\mathrm{cm}^{2}\right)$ & & 482 & $679^{\text {Ns }}$ & 440 & $1138^{*}$ \\
\hline Average lateral length $(\mathrm{cm})$ & & 13 & $13^{\text {ss }}$ & 19 & $18^{\mathrm{NS}}$ \\
\hline Lateral number/cane & & 9 & $10^{\text {ss }}$ & 9 & $10^{\mathrm{ss}}$ \\
\hline Node number/cane & & 29 & $29^{\text {Ns }}$ & 34 & $29^{\mathrm{Ns}}$ \\
\hline Budbreak (\%) & & 31 & $34^{\mathrm{Ns}}$ & 27 & $34^{\mathrm{Ns}}$ \\
\hline Primocane: Diameter (mm) & & 6.5 & $7.1^{*}$ & 6.9 & $7.6^{\mathrm{Ns}}$ \\
\hline Height $(\mathrm{cm})$ & & 52.0 & $55.4^{\mathrm{NS}}$ & 68.3 & $87.4^{*}$ \\
\hline Dry weight (g) & & 92.4 & $88.4^{\mathrm{Ns}}$ & 66.5 & $78.5^{\mathrm{Ns}}$ \\
\hline Node number & & 24 & $24^{\mathrm{Ns}}$ & 29 & $30^{\text {Ns }}$ \\
\hline
\end{tabular}

vs, ****Nonsignificant or significantly different from respective control at $P \leq 0.05$ and 0.01 .

not shown) or whole canes (Table 1) were analyzed. Floricane diameter was similar at the beginning and end of the season for both cultivars and treatments. Primocanes of both cultivars in the staked treatment were $\approx 9.7 \%$ greater in diameter than control primocanes (Table 1). These differences were significant for 'Boyne' and 'Regency' at the 5\% and 10\% level, respectively. Differences in primocane height were nonsignificant for the cultivar 'Boyne', but staked 'Regency' primocanes were $\approx 28 \%$ taller than those of control plants (Table 1).

\section{Discussion}

Cane stabilization resulted in a significant increase in yield per cane in both 'Boyne' and 'Regency' red raspberries, similar to increases found by Prive and Allain (1998) and Waister (1970). Canes that were not staked moved freely in the wind; increased contact with adjacent canes reduced leaf area and increased damage from abrasion (Grace, 1977; Proctor, 1982) in comparison with staked canes. Similar results were seen in Ulmus americana L. seedlings (Telewski and Pruyn, 1998) where average leaf area decreased with increased stem flexure. Shaking inhibits photosynthesis (Grace, 1977), thus leaf photosynthetic rates may have varied between treatments. Extensive abrasion may influence leaf water relations by stimulating stomatal opening (Grace, 1977), further reducing photosynthetic rates. Experiments reported in the literature (Prive and Allain, 1998; Waister, 1970) failed to establish whether the effects of sheltering screens were related to water relations or air movement. Factors other than stabilization may have increased yield. Wind speed was not confounded by treatments in our experiments, as no shelters were used.

A combination of small increases in fruit size and number resulted in the higher yield of staked 'Boyne' plants. The higher yield of the staked 'Regency' plants was a result of more fruits per cane, along with a small (but nonsignificant) increase in fruit size. Preharvest losses of fruit may have occurred in the controls because of cane rubbing. These results are similar to those by Nehrbas and Pritts (1988) and J.E. Vanden Heuvel et al. (unpublished data) where increased yield of trellised plants was attributed to increased fruit number per cane.

Nonstaked trees allocate carbohydrates to structural wood in response to wind movement (Elfving and McKibbon, 1992), resulting in a reduced supply of carbohydrates available for fruit production. However, neither treatment in this study affected the production of structural wood by increasing either diameter or height of floricanes. Since floricane height and diameter are determined in the previous growing season (Jennings, 1988), and all floricanes were formed in the absence of a trellis, no significant differences in fruiting framework between the two treatments were expected.

The staking of floricanes did have an influence on the actively growing primocanes. In both cultivars, primocanes in the staked treatment had greater diameter and cane height than did the controls. Increased cane diameter has been associated with increased yield and yield potential (Dale, 1989). These increases in primocane growth may be attributed to the greater leaf area of the floricanes in those pots. In general, primocanes of both cultivars were low in vigor, possibly because of high root zone temperatures in the pots (Percival et al., 1996).

In contrast with previous research results (Elfving and McKibbon, 1992; Perry, 1989), the increase in fruit production by canes that were prevented from moving freely in the wind seems to be a result of an increase in leaf area on those canes, as opposed to an increase in fruiting framework. These results complement those of Whitney (1982) and Wright and Waister (1982), who related greater cane leaf area and leaf number to increased yield. An increase in fruiting framework in the staked treatments was not expected since the yield potential of a floricane is determined in the previous growing season. Had canes been staked for their entire life cycle, greater differences in growth between the two treatments might have occurred. The increased cane height, diameter, and dry weight of primocanes would be expected to increase yield potential during the following season (Dale, 1989).

In conclusion, cane stabilization increased yield and yield potential in two red raspberry cultivars, and may be a significant contributor to the yield increases observed in trellising studies (Nehrbas and Pritts, 1988; J.E. Vanden Heuvel et al., unpublished data). These results lead us to conclude that the advantages of trellising are not solely confined to improved light penetration but are also due to cane stabilization and enhanced conditions for photosynthesis. However, the relative contributions of improved light penetration and cane stabilization to increased yield in trellising studies are unknown at this time.

\section{Literature Cited}

Dale, A. 1989. Productivity in red raspberries. Hort. Rev. 11:185-228.

Elfving, D.C. and E.D. McKibbon. 1992. Tree support-Another management tool for apple growers. Compact Fruit Tree 25:12 -14.

Forshey, C.G. and M.W. McKee. 1970. Production efficiency of a large and small 'McIntosh' apple tree. HortScience 5:164-165.

Forshey, C.G. and R.W. Weires, Jr. 1983. Dry weight partitioning of 'McIntosh' apple trees. J. Amer. Soc. Hort. Sci. 108:149-154.

Grace, J. 1977. Plant response to wind. Academic, London. 
Jennings, D.L. 1988. Raspberries and blackberries: Their breeding, diseases and growth. Academic, London.

Nehrbas, S.R. and M.P. Pritts. 1988. Effect of training system on performance of hand-harvested summer-bearing raspberries. HortScience 23:126-127.

Percival, D.C., J.T.A. Proctor, and M.J. Tsujita. 1996. Whole-plant net $\mathrm{CO}_{2}$ exchange of raspberry as influenced by air and root-zone temperature, $\mathrm{CO}_{2}$ concentration, irradiation, and humidity. J. Amer. Soc. Hort. Sci. 121:838845 .

Perry, R.L. 1989. Why tree stakes are becoming so popular. Compact Fruit Tree 22:33-36.

Prive, J.P. and N. Allain. 1998. Fruit research report. Agr. and Agri-Food Canada, Bouctouche, N.B.

Proctor, J.T.A. 1982. Wind injury of Anjou pear. Plant Dis. 66:1169-1170.

Telewski, F.W. and M.L. Pruyn. 1998. Thigmomorphogenesis: A dose response to flexing in
Ulmus americana seedlings. Tree Physiol. 18:65-68.

Waister, P.D. 1970. Effects of shelter from wind on the growth and yield of raspberries. J. Hort. Sci. 45:435-445.

Whitney, G.G. 1982. The productivity and carbohydrate economy of a developing stand of Rubus idaeus. Can. J. Bot. 60:2697-2703.

Wright, C.J. and P.D. Waister. 1982. Within-plant competition in the red raspberry. II. Fruiting cane growth. J. Hort. Sci. 57:443-448. 